University of Nebraska - Lincoln

DigitalCommons@University of Nebraska - Lincoln

Publications from USDA-ARS / UNL Faculty

U.S. Department of Agriculture: Agricultural

Research Service, Lincoln, Nebraska

6-4-2003

\title{
Functional properties of waxy wheat flours: genotypic and environmental effects
}

\author{
Robert A. Graybosch \\ University of Nebraska-Lincoln, bob.graybosch@ars.usda.gov \\ Edward Sousa \\ University of Idaho, Aberdeen \\ William Berzonsky \\ North Dakota State University \\ P. Stephen Baenziger \\ University of Nebraska-Lincoln, pbaenziger1@unl.edu \\ Okkyung Chung \\ USDA-ARS
}

Follow this and additional works at: https://digitalcommons.unl.edu/usdaarsfacpub

Part of the Agricultural Science Commons

Graybosch, Robert A.; Sousa, Edward; Berzonsky, William; Baenziger, P. Stephen; and Chung, Okkyung, "Functional properties of waxy wheat flours: genotypic and environmental effects" (2003). Publications from USDA-ARS / UNL Faculty. 184.

https://digitalcommons.unl.edu/usdaarsfacpub/184

This Article is brought to you for free and open access by the U.S. Department of Agriculture: Agricultural Research Service, Lincoln, Nebraska at DigitalCommons@University of Nebraska - Lincoln. It has been accepted for inclusion in Publications from USDA-ARS / UNL Faculty by an authorized administrator of DigitalCommons@University of Nebraska - Lincoln. 


\title{
Functional properties of waxy wheat flours: genotypic and environmental effects ${ }^{\text {is }}$
}

\author{
Robert A. Graybosch ${ }^{\mathrm{a}, *}$, Edward Souza $^{\mathrm{b}}$, William Berzonsky ${ }^{\mathrm{c}}$, P. Stephen Baenziger ${ }^{\mathrm{d}}$, \\ Okkyung Chung ${ }^{\mathrm{e}}$ \\ ${ }^{a}$ USDA-ARS, University of Nebraska, East Campus, 344 Keim Hall, Lincoln, NE 68583, USA \\ ${ }^{\mathrm{b}}$ University of Idaho, Aberdeen, ID, USA \\ ${ }^{\mathrm{c}}$ North Dakota State University, Fargo, ND, USA \\ ${ }^{\mathrm{d}}$ University of Nebraska, Lincoln, NE, USA \\ ${ }^{\mathrm{e}}$ USDA-ARS, Grain Marketing and Production Research Lab, Manhattan, KS, USA
}

Received 25 July 2002; revised 3 December 2002; accepted 3 December 2002

\begin{abstract}
A set of waxy (amylose-free) experimental spring wheats (Triticum aestivum L.) of diverse parentage were grown, along with two nonwaxy and two partial waxy check cultivars, at diverse North American cultural environments. Grain yield and functional attributes of derived flours were determined. Average grain yield of the waxy lines did not differ significantly from the average yield of the check cultivars, but significant differences were observed amongst the waxy lines. Grain hardness varied significantly amongst the waxy lines, and both hard and soft textured waxy lines were identified. Analysis of flour quality traits showed few differences between waxy lines and check cultivars for traits primarily related to protein concentration or protein quality, but many significant differences between properties primarily dependent upon starch structure, or related to milling behavior. Protein-related quality attributes of waxy wheats demonstrated environmental and genotypic variances similar to those typical of non-waxy wheats. Starch-related quality attributes of waxy wheats showed remarkable stability across environments, but some significant genetic variation was observed. End-users interested in employing waxy wheats should be able to select desired waxy lines, and feel confident that the starch-related functional properties will be environmentally stable.

Published by Elsevier Science Ltd.
\end{abstract}

Keywords: Waxy wheat; Starch; Flour quality; Genotype and environmental effects

\section{Introduction}

Waxy (amylose-free) wheats (Triticum aestivum L.) have been developed via classical breeding and genetics (Nakamura et al., 1995). Many uses have been suggested for waxy wheat, including a source of blending flour to improve shelf-life stability, processing quality or palatability of baked and sheeted wheat products (Hoshino et al., 2000a,b; Lee et al., 2001), or as a substitute for waxy maize

\footnotetext{
Joint contribution of the United States Department of Agriculture, Agricultural Research Service and the Department of Agronomy, University of Nebraska-Lincoln as Journal Series Paper No.13787. Mention of firm names or trade products does not imply that they are endorsed or recommended by the USDA or the University of Nebraska over other firms or products not mentioned.

* Corresponding author. Tel.: + 1-402-472-1563; fax: + 1-402-472-4020.

E-mail address: rag@unlserve.unl.edu (R.A. Graybosch).
}

in the production of modified starches (Reddy and Seib, 2000). Waxy wheat breeding programs are underway in a number of countries (Graybosch, 1998), but commercial cultivation of waxy wheat, at least in the United States, has yet to be initiated.

Waxy wheats carry null (non-functional) alleles at the three loci encoding the granule-bound starch synthase (Nakamura et al., 1995) (GBSS), also known as the "waxy protein'. GBSS catalyzes the synthesis of amylose. Waxy lines produce endosperm starch consisting only of amylopectin. Whereas the loss of amylose is a dramatic event in terms of impact on starch structure, it is likely that other genes might also influence functional properties of waxy wheats. In addition, wheat flour properties are determined by the combined interactions of starch, protein, lipids, pentosans, etc. Thus, it is important to determine to what extent waxy flour properties will vary as a function of 
genetic background. In addition, it is well known (Peterson et al., 1992, 1998) that quality of typical, non-waxy (wildtype) wheat varies due to the combined effects of genotype, environment, and their interactions.

The goal of this study was to determine whether the functional properties of waxy wheats are modified by genetic backgrounds and by cultural environments, or whether the altered starch structure is of sufficient magnitude to render such effects inconsequential. Potential end-users of waxy wheat shall then be able to determine whether waxy wheat per se will suit their needs, or whether they need to identify specific waxy cultivars and cultural environments as sources of flours for their products.

\section{Materials and methods}

Traditional breeding techniques were used to produce a set of spring waxy wheats in diverse genetic backgrounds (Table 1). Samples of these waxy wheat lines have been deposited in the USDA-ARS National Small Grains Collection, Aberdeen, Idaho, USA. Pedigrees are

Table 1

Identification and pedigrees of waxy wheat lines

\begin{tabular}{|c|c|c|}
\hline Line & PI number ${ }^{\mathrm{a}}$ & Pedigree \\
\hline 99ID388 & 619354 & $\begin{array}{l}\text { Kanto107/MN2540/3/Bai } \\
\text { Huo5/K94H115//IDO469 }\end{array}$ \\
\hline 99ID389 & 619355 & $\begin{array}{l}\text { Kanto107/MN2540/3/Bai } \\
\text { Huo5/K94H115//IDO469 }\end{array}$ \\
\hline 99ID435 & 619356 & $\begin{array}{l}\text { BaiHuo/L910097//Kanto107 } \\
\text { /3/Kanto107/Yanshi9 }\end{array}$ \\
\hline 99ID450 & 619357 & BaiHuo3/Cimarron//MN91227/3/Kanto107 \\
\hline 99ID477 & 619359 & BaiHuo/Chris//Kanto107 \\
\hline 99ID484 & 619360 & $\begin{array}{l}\text { BaiHuo/L910097//Kanto107/3/ } \\
\text { BaiHuo3/Cimarron//MN91227 }\end{array}$ \\
\hline 99ID490 & 619361 & BaiHuo/Kanto107//Express \\
\hline 99ID496 & 619362 & BaiHuo/Kanto107//Express \\
\hline 99ID498 & 619363 & BaiHuo/Kanto107//Express \\
\hline 99ID516 & 619365 & $\begin{array}{l}\text { KY87C-42-8-5/Collin//ACMajestic } \\
\text { /3/Kanto107/BaiHuo }\end{array}$ \\
\hline 99ID520 & 619366 & $\begin{array}{l}\text { KY87C-42-8-5/Collin//ACMajestic } \\
\text { /3/Kanto107/BaiHuo }\end{array}$ \\
\hline 99ID524 & 619367 & $\begin{array}{l}\text { KY87C-42-8-5/Collin//ACMajestic } \\
\text { /3/Kanto107/BaiHuo }\end{array}$ \\
\hline 99ID529 & 619368 & $\begin{array}{l}\text { KY87C-42-8-5/Collin//ACMajestic } \\
\text { /3/Kanto107/BaiHuo }\end{array}$ \\
\hline 99ID536 & 619369 & $\begin{array}{l}\text { KY87C-42-8-5/Collin//ACMajestic } \\
\text { /3/Kanto107/BaiHuo }\end{array}$ \\
\hline 99ID546 & 619370 & $\begin{array}{l}\text { Penawawa/NE92608//BaiHuo/3/ } \\
\text { BaiHuo4/Kanto107//A92-3327/Kanto107 }\end{array}$ \\
\hline 99ID548 & 619371 & $\begin{array}{l}\text { Penawawa/NE92608//BaiHuo/3/BaiHuo4 } \\
\text { /Kanto107//A92-3327/Kanto107 }\end{array}$ \\
\hline 99ID554 & 619372 & Kanto107/BaiHuo//BaiHuo/Russ \\
\hline 99ID569 & 619373 & BaiHuo/Kanto107//ACMajestic \\
\hline 99ID590 & 619374 & BaiHuo/ACMajestic//Kanto107/MN2540 \\
\hline 99ID594 & 619375 & BaiHuo/Gunnar//Kanto107/Penawawa \\
\hline
\end{tabular}

\footnotetext{
${ }^{\text {a }}$ Plant Introduction (PI) number, USDA-ARS, National Small Grains Collection, Aberdeen, ID, USA.
}

designated using the system of Purdy et al. (1968). After completion of the final mating in each combination, $F_{1}$ plants were sown in greenhouses on the East Campus of the University of Nebraska, Lincoln, USA. The brush end of $F_{2}$ seed harvested from $F_{1}$ plants was stained with a dilute solution of $\mathrm{I}_{2} \mathrm{KI}$ (Berlyn and Miksche, 1976) and the germ end was saved for planting. Under these staining conditions, waxy seeds were identified by their red-brown color, as opposed to the dark purple-black color typical of wild-type or partial waxy lines. $F_{2}$ plants were grown, without vernalization, in the greenhouses in the fall of 1998, and maintained and harvested individually. Only true spring growth habit types (e.g. those that flowered and set seed under non-vernalizing conditions) were harvested. $\mathrm{F}_{2}$-derived $\mathrm{F}_{3}$ single-plant progeny rows were grown at Aberdeen, Idaho, USA in the spring of 1999. At harvest, 22 lines were selected from these progeny rows, based primarily on uniformity of phenotype under field conditions. Two lines later were discarded when they were found to not breed true for the waxy trait.

The waxy lines were sown in replicated field trials in Yuma, Arizona; Fargo, North Dakota; Aberdeen, Idaho and Mead, Nebraska, all in the USA. The Yuma trial was sown in November of 1999 and harvested in May of 2000. The Fargo and Aberdeen trials were sown in the spring of 2000 and harvested the following summer. The Mead trial was grown during 2001. Yuma, Aberdeen and Fargo trials consisted of two replications arranged in randomized complete block designs. The Mead trial had three field replications. Fargo and Mead trials were grown under dryland conditions. The Yuma and Aberdeen trials were irrigated. Four non-waxy spring wheats, 'Klassic', A95631Js-4-3, 'Express' and 'WPB926' were included as checks (controls). Express and WPB926 are wild-type (functional alleles at all three $w x$ loci). Klassic carries two functional alleles and a null allele at the $w x-B 1$ locus. A95631-Js-4-3 has null alleles at the $w x-A 1$ and $w x-B l$ loci. Grain yields were determined from the Fargo, Aberdeen and Mead sites. Quality attributes were measured on grain harvested from Yuma, Aberdeen and Fargo. In statistical computations, each trial was considered a separate random environment.

Average grain weight and grain hardness were scored on a 300 seed per plot sample using a Perten (Springfield, IL, USA) Single Kernel Characterization System (AACC Method 55-31) (AACC, 2000). Grain and flour ash and protein $(14 \% \mathrm{mb})$ concentration were measured by nearinfrared reflectance (NIR). Laboratory values for protein concentration and subsequent equation development and calibration checks were determined by nitrogen combustion method (AACC Method 46-30). Ash contents were predicted by an NIRSystems 6500, using calibrations developed at the USDA/ARS/Hard Winter Wheat Quality Laboratory by adapting the AACC Method 08-21, using the NIR guidelines for prediction model development (AACC Method 39-00) and the basic furnace ash method (AACC 08-01) as a reference method. All wheats (checks and waxy) 
were conditioned (tempered) to $15 \% \mathrm{mc}$ by: (a) adding $26-$ $40 \mathrm{~g}$ water (depending on the original moisture content of wheat) to $500 \mathrm{~g}$ (on 'as is moisture basis') and blending for 30-40 min in a closed tumbling container; and (b) leaving the blended wheat overnight $(16 \mathrm{~h})$. Tempered wheat $(15 \%$ $\mathrm{mb}$ ) was milled on an experimental Brabender Quadrumat Sr. Mill (C.W. Brabender, Inc., Hackensack, NJ, USA). Sodium dodecyl sulphate (SDS) sedimentation volume was determined on flour via AACC Method 56-60. Mixograph (National Manufacturing, Lincoln, NE, USA) variables (AACC Method 54-40) were recorded as follows: Absorption $=$ optimal water added ( $\%$ of flour wt. on $14 \%$ $\mathrm{mb}$ ), Mix Time = time in minutes, to peak dough development, Tolerance $=$ resistance of dough to overmixing ( $0=$ unsatisfactory, $4=$ satisfactory, $6=$ outstanding $)$. Rapid Visco Analyser (RVA) (AACC Method 61-02) was used to investigate flour pasting profiles.

All statistical computations were made using SAS Version 8 for Windows programs (SAS Institute, Cary, NC, USA). Analysis of variance was used to test for significant differences among or between environments, replications within environments, check cultivars, waxy lines and the contrast of checks vs. waxy lines. Interaction terms also were computed, and appropriate mean squares were used to calculate $F$-statistics for tests of significance. Least significant differences (1.s.d. $p=0.05$ ) were used to compare mean values within the waxy class. Variance components ( $\%$ of total variance attributed to each main and interaction effect) were calculated using the Proc Varcomp procedure. Simple correlations were determined on a per sample basis. Correlations were obtained between RVA variables and all other grain and flour attributes.

\section{Results and discussion}

Significant differences in grain yield were observed amongst environments, and amongst the waxy lines, but no significant differences were observed amongst the check cultivars, nor was the contrast of checks vs. waxy significant (data not shown). The lack of significance in the check vs. waxy contrast might suggest that a grain yield penalty will not be associated with use of the waxy trait in wheat breeding programs. Definitive studies to compare potential yield effects with near-isogenic lines would be useful in addressing this question.

Significant environmental variation occurred for all grain and flour quality traits except for the RVA peak, trough, final and setback viscosities, and RVA peak time (Table 2). The lack of RVA environmental effects, and RVA peak viscosities generally $>200$ units, indicates the samples all were obtained from sound (non-sprouted) wheats (Kruger, 1990).

Regarding non-RVA quality traits, significant differences between checks and waxy lines were observed only in SDS sedimentation volume, flour yield and flour ash (Table 2). Flour ash was significantly higher in the waxy

Table 2

Analysis of variance of grain and flour quality traits of 20 waxy spring wheats and non-waxy controls grown at 3 US locations

\begin{tabular}{|c|c|c|c|c|c|c|c|c|c|c|}
\hline Source & $\mathrm{df}$ & $\begin{array}{l}\text { Seed } \\
\text { weight }\end{array}$ & $\begin{array}{l}\text { Grain } \\
\text { hardness }\end{array}$ & $\begin{array}{l}\text { Grain } \\
\text { ash }\end{array}$ & $\begin{array}{l}\text { Grain } \\
\text { protein }\end{array}$ & $\begin{array}{l}\text { SDS sed. } \\
\text { volume }\end{array}$ & $\begin{array}{l}\text { Flour } \\
\text { yield }\end{array}$ & $\begin{array}{l}\text { Flour } \\
\text { ash }\end{array}$ & $\begin{array}{l}\text { Flour } \\
\text { protein }\end{array}$ & $\begin{array}{l}\text { Mixograph } \\
\text { absorption }\end{array}$ \\
\hline Environment & 2 & $1968.1 *$ & $2339^{*}$ & $0.50 *$ & $24.11 *$ & $1990 *$ & $262.8 *$ & $0.05^{*}$ & $22.63 *$ & $69 *$ \\
\hline Rep(Environment) & 3 & 3.4 & 18 & 0.01 & 0.9 & 13 & 1.6 & 0.0002 & 0.84 & 3 \\
\hline Checks vs. Waxy & 1 & 498.5 & 138 & 0.26 & 5.35 & $1293^{*}$ & $2433.4 *$ & $0.38 *$ & 0.25 & 1 \\
\hline Within Checks & 3 & 125.8 & $1090 *$ & $0.5^{*}$ & $10.10 *$ & $503 *$ & $120.8^{*}$ & $0.002 *$ & $8.5^{*}$ & $25^{*}$ \\
\hline Within Waxy & 19 & $30.2 *$ & $700 *$ & 0.03 & $3.4^{*}$ & $85^{*}$ & $139.8 *$ & $0.002 *$ & $3.1 *$ & $8^{*}$ \\
\hline Environment $\times$ Checks & 6 & $50.5^{*}$ & 82 & 0.35 & 0.39 & 10 & 8.7 & 0.0007 & 0.30 & 1 \\
\hline Environment $\times$ Waxy & 38 & 11.6 & 25 & 0.02 & 0.91 & 19 & 11.4 & 0.0004 & 0.70 & 2 \\
\hline Environment $x$ & 2 & $216.8 *$ & 176 & $0.14 *$ & 0.88 & 89 & 52.6 & 0.0005 & 0.99 & 3 \\
\hline \multicolumn{11}{|l|}{ Checks vs. Waxy } \\
\hline Error & 134 & 13.2 & 139 & 0.04 & 1.14 & 32 & 29.4 & 0.0006 & 0.98 & 3 \\
\hline Source & df & $\begin{array}{l}\text { Mixograph } \\
\text { peak time }\end{array}$ & $\begin{array}{l}\text { Mixograph } \\
\text { tolerance }\end{array}$ & $\begin{array}{l}\text { RVA peak } \\
\text { viscosity }\end{array}$ & $\begin{array}{l}\text { RVA trough } \\
\text { viscosity }\end{array}$ & $\begin{array}{l}\text { RVA break- } \\
\text { down }\end{array}$ & $\begin{array}{l}\text { RVA final } \\
\text { viscosity }\end{array}$ & $\begin{array}{l}\text { RVA } \\
\text { setback }\end{array}$ & $\begin{array}{l}\text { RVA peak } \\
\text { time }\end{array}$ & $\begin{array}{l}\text { RVA pas- } \\
\text { ting temp. }\end{array}$ \\
\hline Environment & 2 & $11.2 *$ & $51 *$ & 3473 & 267 & $2051^{*}$ & 776 & 203 & 0.02 & $17.6^{*}$ \\
\hline Rep(Environment) & 3 & 0.1 & 0.01 & 399 & 133 & 132 & 251 & 58 & 0.002 & 0.2 \\
\hline Checks vs. Waxy & 1 & 41.6 & 14 & 1260 & $42,230 *$ & $28,904 *$ & $237,127 *$ & $79,209 *$ & $114.52 *$ & 0.7 \\
\hline Within Checks & 3 & 7.5 & 3 & 354 & $770^{*}$ & $2029 *$ & 1464 & 178 & 0.1 & $8.4^{*}$ \\
\hline Within Waxy & 19 & $0.5^{*}$ & 2 & $2172^{*}$ & $214 *$ & $1158^{*}$ & $416^{*}$ & 67 & $0.03 *$ & $4.5^{*}$ \\
\hline Environment $\times$ Checks & 6 & $3 *$ & 1 & 132 & 124 & 89 & 305 & 64 & $0.01 *$ & 0.7 \\
\hline Environment $\times$ Waxy & 38 & 0.1 & $1 *$ & 290 & 22 & 194 & 69 & 35 & $0.005^{*}$ & 0.6 \\
\hline Environment $\times$ & 2 & $3.0 *$ & $5 *$ & 291 & 62 & 472 & 1 & $257 *$ & $0.08 *$ & 1.8 \\
\hline \multicolumn{11}{|l|}{ Checks vs. Waxy } \\
\hline Error & 134 & 0.4 & 1 & 538 & 77 & 364 & 183 & 57 & 0.001 & 1.2 \\
\hline
\end{tabular}

*significant at $p=0.05$. 
Table 3

Mean values, grain and flour quality traits, for 20 spring waxy wheats and non-waxy controls grown at 3 US locations

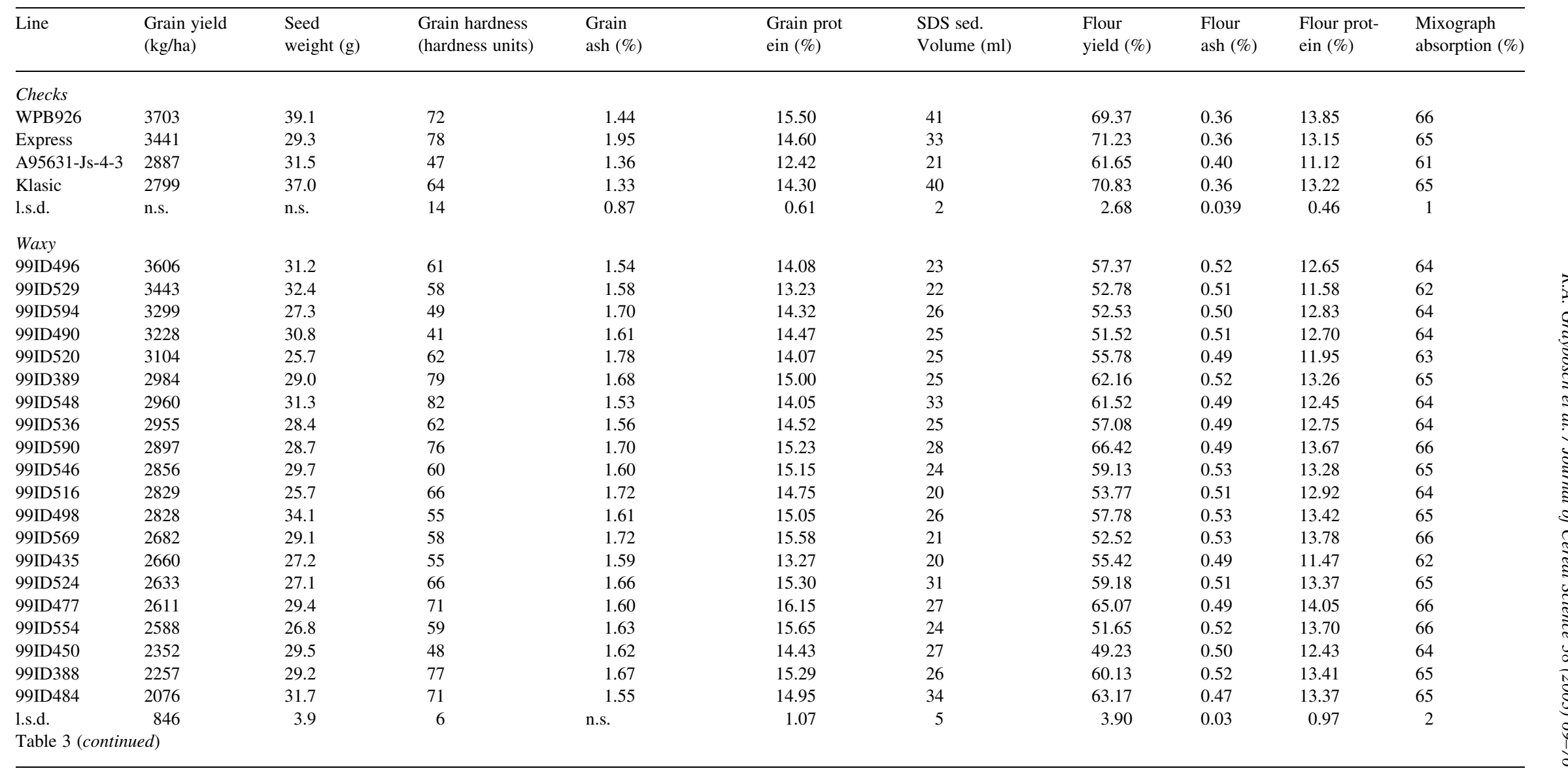

Line Mixograph peak Mixograph tole RVA peak viscosity rance $(0-4)$ (RVA units)

RVA trough
(RVA units)

RVA break-dow

RVA final viscosity RVA setback RVA peak RVA pasting

Checks

WPB926

218.5

(RVA units)

(RVA units) time (min) temp. $\left({ }^{\circ} \mathrm{C}\right)$

Express

218.5

145.7

72.8

241.5

$78.8 \quad 238.0$

A956315 1.8

Klasic

230.5

136.4

1.s.d.

4.4

$\begin{array}{ll}0.7 & 230.5 \\ 2.0 & 229.2\end{array}$

121.3

109.2

105.2

210.5

Waxy

99ID496

n.s.

16.4

215.6

$\begin{array}{rrr}95.8 & 6.1 & 64.1 \\ 101.7 & 6.1 & 65.3 \\ 89.2 & 5.9 & 67.0 \\ 91.6 & 5.9 & 65.1 \\ \text { n.s. } & 0.1 & 0.8\end{array}$

99ID52

1.4
2.1

$\begin{array}{ll}0.3 & 211.8\end{array}$

84.6

127.2

n.s.

0.8

(

214.5

85.5

129.2

113.2

$\begin{array}{ll}28.3 & 3.7 \\ 27.9 & 3.6\end{array}$

65.8 


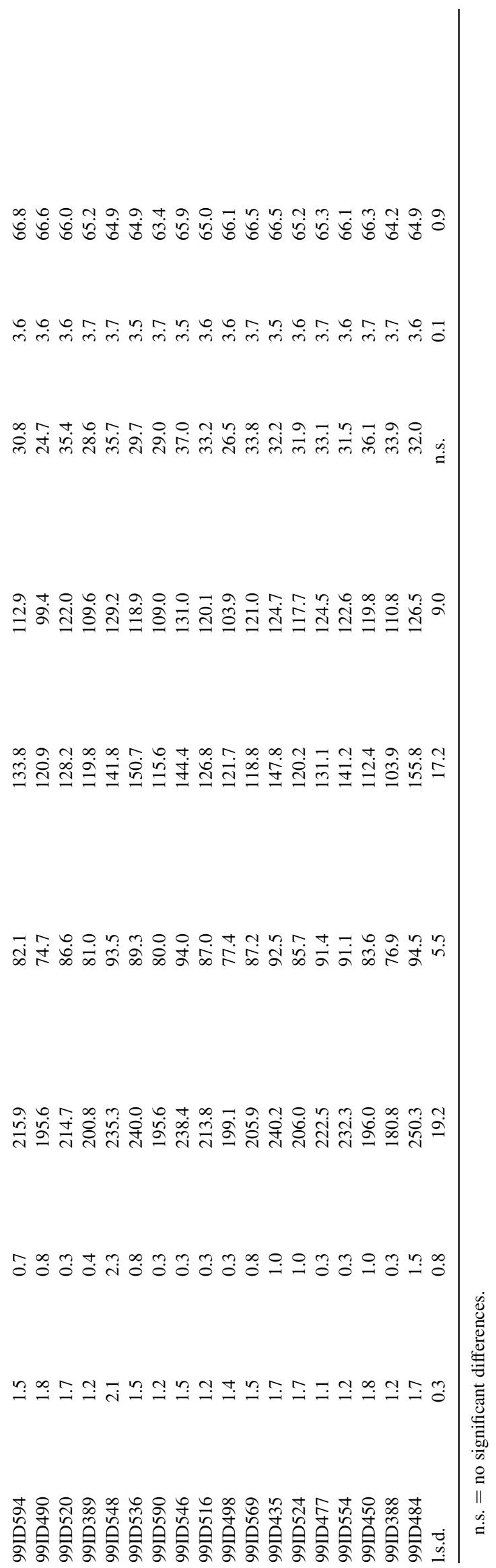

lines, while SDS sedimentation volumes and flour yield were significantly lower (Table 3). Mean Mixograph peak times and tolerance scores of the waxy lines (Table 3 ) were relatively low; hence, it is not known whether the low SDS sedimentation volumes observed in this set of waxy wheats is a function of the waxy character, or is merely a reflection of the poor gluten strength of this particular set of lines. The lower flour extraction rate may be related directly to the waxy character. Flour yield is not related to gluten strength, and, it previously has been reported (Bettge et al., 2000) that waxy wheats tend to produce higher starch damage when milled. This suggests some aspect of waxy endosperm, perhaps the higher crystallinity of the starch granules due to the lack of amylose, influences the milling properties of waxy wheat. Significant differences between waxy lines and checks were most evident in the RVA variables. RVA peak viscosity and pasting temperature did not differ significantly between these two classes, but all other RVA traits did (Tables 2 and 3). Waxy wheats reached peak viscosity at a mean time of 3.6 min, nearly half the time $(6.0 \mathrm{~min})$ observed for the checks (Table 3 ). Pasting temperature is defined by the manufacturer of the RVA (Newport Scientific, Warriewood NSW, Australia) as the temperature at which starch swelling is initiated, and it differs from peak time, the time at which peak viscosity is attained. The observation that flour pasting occurs at roughly the same temperature in waxy and non-waxy wheat, but waxy wheats attain peak viscosity at a lower temperature than non-waxy, is in agreement with previous work (Graybosch et al., 2000). Mean trough, setback and final viscosities of waxy wheats were significantly lower, and breakdown viscosities correspondingly higher, than those of the checks (Table 3).

Amongst the waxy lines, significant differences were observed for all traits except for grain ash concentration and RVA setback viscosity (Tables 2 and 3). Mean grain yields of the waxy lines varied widely, from a low of $2076 \mathrm{~kg} \mathrm{ha}^{-1}$ to a high of $3606 \mathrm{~kg} \mathrm{ha}^{-1}$, with the latter being nearly equal to that of the highest yielding check cultivar. The significant variation observed in the non-RVA related quality traits suggests that improvement in these traits, via traditional breeding and selection, is possible amongst waxy wheats. Significant variation was observed amongst the waxy lines in grain hardness. Most waxy lines had mean hardness scores above 50, and were classified as hard wheats. Three lines had mean values below 50 , indicative of soft wheat endosperm. This observation confirms previous conclusions (Morris and Konzak, 2001) that grain hardness is independent of starch amylose concentrations, and that waxy wheats may be developed with desired endosperm textures. It also suggests a possible means of alleviating the observed (Bettge et al., 2000) elevation in damaged starch of waxy grain after milling. Use of the waxy trait in soft-textured backgrounds might diminish this effect.

The most consistent differences between waxy and check cultivars (see above) were in RVA variables, especially 
Table 4

Percentage of total variance in grain and flour quality traits of waxy wheats contributed by respective sources of variance

\begin{tabular}{|c|c|c|c|c|c|}
\hline Variable & Environment & Rep(Environment) & Line & Environment $\times$ line & Error \\
\hline Seed weight & 78.10 & 0.44 & 7.34 & 12.53 & 1.58 \\
\hline Grain hardness & 22.48 & 0.62 & 66.53 & 4.56 & 5.81 \\
\hline Grain ash & 38.07 & 1.82 & 6.13 & 40.88 & 13.09 \\
\hline Grain protein & 26.53 & 4.18 & 27.79 & 20.45 & 21.05 \\
\hline SDS sed. volume & 66.69 & 0.59 & 15.53 & 7.47 & 9.73 \\
\hline Flour yield & 16.82 & 2.61 & 55.42 & 7.01 & 18.14 \\
\hline Flour ash & 58.93 & 0.04 & 13.92 & 8.20 & 18.92 \\
\hline Flour protein & 27.67 & 4.78 & 28.22 & 17.34 & 22.00 \\
\hline Mixograph absorption & 30.32 & 4.93 & 25.52 & 14.98 & 24.25 \\
\hline Mixograph peak time & 48.18 & 0.00 & 23.29 & 1.33 & 27.83 \\
\hline Mixograph tolerance & 60.42 & 0.00 & 17.25 & 14.09 & 8.63 \\
\hline RVA peak viscosity & 11.76 & 0.15 & 46.07 & 1.54 & 40.49 \\
\hline RVA trough viscosity & 11.79 & 2.67 & 56.08 & 9.54 & 19.92 \\
\hline RVA break-down & 11.59 & 0.23 & 36.96 & 0.23 & 50.99 \\
\hline RVA setback & 3.28 & 0.86 & 9.06 & 1.55 & 85.26 \\
\hline RVA peak time & 0.01 & 0.74 & 39.12 & 8.22 & 51.91 \\
\hline RVA pasting temperature & 18.69 & 0.01 & 46.78 & 13.18 & 21.34 \\
\hline
\end{tabular}

trough and final viscosities, and peak time. The significant differences observed amongst the waxy lines for these traits suggest that factors other than starch amylose content influence flour pasting behavior. While significant differences existed amongst waxy lines for mean RVA peak time, the range of response was quite narrow, probably of little practical significance, and possibly merely a reflection of the precision of the test. Variation for mean RVA trough and final viscosities amongst the waxy lines was more extensive, and suggestive of the possibilities of identifying waxy lines with desired viscosity patterns, and of improving the traits via selection.

When the total variance in waxy wheat quality was apportioned to main effects and interactions by computation of variance components (Table 4), many of the non-RVA traits were found to vary in a manner similar to that previously reported for non-waxy wheats (Peterson et al., 1998; Purdy et al., 1968). Environment was the largest source of variance for seed weight, SDS sedimentation volume, flour ash and Mixograph peak time and tolerance. Variance in grain ash, grain and flour protein and Mixograph absorption was distributed approximately equally over environment, line (genotype) and line $x$ environment interactions. The RVA variables showed a totally different pattern. The largest source of variance was line, with environmental effects being slight, and line $\times$ environment effects being negligible. Of the non-RVA variables, only grain hardness and flour yield demonstrated a similar pattern. These observations suggest that once the functional properties of a particular waxy line have been documented, end-users can expect, in the absence of preharvest sprouting, stable RVA responses over diverse environments, but grain and protein related variables will vary in a manner similar to non-waxy wheats.

Even though RVA responses of waxy lines were stable across diverse environments, significant variation did exist amongst the waxy lines (Tables 2 and 3). In an attempt to understand possible sources of this variation, simple correlations were calculated between the RVA variables, and the remaining quality traits (Table 5). Similar correlations were calculated independently for the samples of check cultivars (Table 6). Some similarities between the two groups were noted. In both sets, grain hardness was positively correlated with several viscosity

Table 5

Significant $(p<0.05)$ correlations between RVA variables and remaining quality traits, waxy wheats, $n=119$

\begin{tabular}{|c|c|c|c|c|c|c|c|c|c|c|c|c|}
\hline & & Seed weight & $\begin{array}{l}\text { Grain } \\
\text { hardness }\end{array}$ & $\begin{array}{l}\text { Grain } \\
\text { ash }\end{array}$ & $\begin{array}{l}\text { Grain } \\
\text { protein }\end{array}$ & $\begin{array}{l}\text { SDS sed. } \\
\text { volume }\end{array}$ & $\begin{array}{l}\text { Flour } \\
\text { yield }\end{array}$ & $\begin{array}{l}\text { Flour } \\
\text { ash }\end{array}$ & $\begin{array}{l}\text { Flour } \\
\text { protein }\end{array}$ & $\begin{array}{l}\text { Mixograph } \\
\text { absorption }\end{array}$ & $\begin{array}{l}\text { Mixograph } \\
\text { peak time }\end{array}$ & $\begin{array}{l}\text { Mixograph } \\
\text { tolerance }\end{array}$ \\
\hline RVA peak viscosity & $\mathrm{r}$ & & & -0.18 & -0.31 & & 0.19 & -0.31 & -0.29 & -0.28 & & \\
\hline RVA trough viscosity & $\mathrm{r}$ & & 0.23 & & & & 0.24 & -0.37 & -0.21 & -0.18 & 0.21 & 0.19 \\
\hline RVA break-down & $\mathrm{r}$ & & & -0.21 & -0.33 & & & -0.25 & -0.29 & -0.29 & & \\
\hline RVA final viscosity & $\mathrm{r}$ & & 0.26 & & & 0.28 & 0.23 & -0.35 & & & 0.35 & 0.23 \\
\hline RVA setback & $\mathrm{r}$ & & 0.19 & & & 0.30 & & & & & 0.34 & 0.16 \\
\hline RVA peak time & $\mathrm{r}$ & & 0.24 & 0.19 & 0.28 & & & & 0.27 & 0.29 & & \\
\hline $\begin{array}{l}\text { RVA pasting } \\
\text { Temperature }\end{array}$ & $\mathrm{r}$ & -0.35 & 0.41 & 0.32 & & & -0.50 & & & & 0.46 & 0.30 \\
\hline
\end{tabular}


Table 6

Significant $(p<0.05)$ correlations between RVA variables and remaining quality traits, check cultivars, $n=24$

\begin{tabular}{|c|c|c|c|c|c|c|c|c|c|c|c|c|}
\hline & & $\begin{array}{l}\text { Seed } \\
\text { weight }\end{array}$ & $\begin{array}{l}\text { Grain } \\
\text { hardness }\end{array}$ & $\begin{array}{l}\text { Grain } \\
\text { ash }\end{array}$ & $\begin{array}{l}\text { Grain } \\
\text { protein }\end{array}$ & $\begin{array}{l}\text { SDS sed. } \\
\text { volume }\end{array}$ & $\begin{array}{l}\text { Flour } \\
\text { yield }\end{array}$ & Flour ash & $\begin{array}{l}\text { Flour } \\
\text { protein }\end{array}$ & $\begin{array}{l}\text { Mixograph } \\
\text { absorption }\end{array}$ & $\begin{array}{l}\text { Mixograph } \\
\text { peak time }\end{array}$ & $\begin{array}{l}\text { Mixograph } \\
\text { tolerance }\end{array}$ \\
\hline RVA peak viscosity & $\mathrm{r}$ & & & & -0.43 & & & & -0.43 & -0.39 & & \\
\hline RVA trough viscosity & $\mathrm{r}$ & & 0.43 & & & & & & & & & \\
\hline RVA break-down & $\mathrm{r}$ & & -0.35 & & -0.69 & & -0.45 & & -0.62 & -0.59 & & \\
\hline RVA final viscosity & $\mathrm{r}$ & & 0.58 & & & & & & & & & \\
\hline RVA setback & $\mathrm{r}$ & & 0.69 & 0.57 & & & & & & & 0.42 & \\
\hline RVA peak time & $\mathrm{r}$ & & & & 0.67 & & & & 0.60 & 0.59 & & \\
\hline RVA pasting & $\mathrm{r}$ & -0.77 & & & & -0.42 & -0.78 & 0.61 & & & & \\
\hline Temperature & & & & & & & & & & & & \\
\hline
\end{tabular}

measures. Grain and flour protein concentrations, and Mixograph absorption (a variable partially dependent upon protein concentrations) were negatively correlated with RVA viscosity measurements, while Mixograph time and Mixograph tolerance, variables at least partially dependent upon gluten strength, were positively correlated. Higher protein (and hence, lower total starch content) might have a dilution effect, thereby preventing closer interactions between swelling starch granules during the process of pasting, hence depressing viscosities. Gluten strength might counteract this effect, if tighter associations between protein molecules exert some resistance to the mixing action of the RVA. It has been demonstrated (Morris et al., 1997; Batey, 2000) that the addition of gluten to flour samples increased peak viscosity, perhaps via competition for water. In a related genetic study (Batey, 2000) it was shown that contrasting alleles encoding high molecular weight glutenin proteins had little effect on peak viscosity, but did alter gelatinization temperatures as measured by differential scanning calorimetry. Grain hardness also might exert an effect via elevated damaged starch and altered water absorption in harder grains.

The correlations demonstrate that RVA pasting behaviors of wheat flours are influenced by factors in addition to starch amylose content, and that the effects are at least somewhat consistent between waxy and non-waxy wheats. The correlations also demonstrate that some of the inherent differences in pasting behavior that were detected amongst the waxy wheats might arise from non-starch factors. While the waxy loci may be considered major genes conditioning flour-pasting properties (Zeng et al., 1997), no doubt a suite of minor genes contributes to the observed genetic variation (Udall et al., 1999; Batey et al., 2001). Additional biochemical factors that might influence the flour-pasting properties of sound wheat include the proportion of small starch granules (Wootton et al., 1998), starch lipid composition (Takahashi and Seib, 1988) and components of the water-soluble fraction of wheat flours (Morris et al., 1997). In the absence of variation for amylose content, genetic or environmentally induced variation in these other flour components could be contributing to the observed variation.

Previous studies have given inconsistent results when waxy and non-waxy wheat RVA peak viscosities were compared
(Kiribuchi-Otobe et al., 1997; Hayakawa et al., 1997). In the present study, no differences in mean values of the two classes were detected, but significant differences were detected within the waxy class. Thus, whether or not waxy flours give higher peak viscosities than non-waxy will be dependent upon the specific waxy and non-waxy wheats under study.

\section{Conclusions}

A set of waxy wheats was found to differ primarily from non-waxy check cultivars in flour properties (e.g. RVA variables) that for the most part arise from starch attributes or to milling properties. RVA attributes of waxy wheats were found to be remarkably consistent across environments. Genetic variation amongst waxy wheats existed for most flour quality attributes, suggesting that waxy lines might be selected for diverse end-uses. Once a desired waxy wheat line is identified, end-users can expect a fairly consistent product in terms of starch-related quality traits. Grain and protein related traits will vary in a manner similar to that observed for non-waxy wheats.

\section{Acknowledgements}

The authors wish to acknowledge the technical assistance of Brad Seabourn, Laura McLaughlin, Richard Samson, Lori Divis and Cody Eastman. This project was partially supported by a grant from the Nebraska Wheat Board to R.A. Graybosch, and from a grant from the Fund for Rural America to The University of Idaho.

\section{References}

AACC, 2000. Approved methods of the American Association of Cereal Chemists. American Association of Cereal Chemists, St Paul, MN, USA.

Batey, I.L., 2000. Interactions of starch with glutens having different glutenin sub-units. In: Shewry, P.R., Tatham, A.S. (Eds.), Wheat Gluten, Royal Society of Chemistry, Cambridge, UK, pp. 499-502.

Batey, I.L., Hayden, M.J., Cai, S., Sharp, P.J., Cornish, G.B., Morell, M.K., Appels, R., 2001. Genetic mapping of commercially significant starch characteristics in wheat crosses. Aust. J. Agric. Res. 52, 1287-1296. 
Berlyn, G.P., Miksche, J.P., 1976. Botanical microtechnique and cytochemistry, The Iowa State University Press, Ames, IA, USA.

Bettge, A.D., Giroux, M.J., Morris, C.F., 2000. Susceptibility of waxy starch granules to mechanical damage. Cereal Chem. 77, 750-753.

Graybosch, R.A., 1998. Waxy wheats: origin, properties and prospects. Trends Food Sci. Technol. 9, 135-142.

Graybosch, R.A., Guo, G., Shelton, D.R., 2000. Aberrant falling numbers of waxy wheats independent of alpha-amylase activity. Cereal Chem. 77, $1-3$.

Hayakawa, K., Tanaka, K., Nakamura, T., Endo, S., Hoshion, T., 1997. Quality characteristics of waxy hexaploid wheat (Triticum aestivum L.): properties of starch gelatinization and retrogradation. Cereal Chem. 74, $576-580$.

Hoshino, T., Yoshikawa, R., Ito, S., Hatta, K., Nakamura, T., Yamamori, M., Hayakawa, K., Tanaka, K., Akashi, H., Endo, S., Tago, S., Ishigami, S., 2000. Flour blends for breads, cakes, or noodles, and foods prepared from the flour blends. United States Patent 6,042,867.

Hoshino, T., Yoshikawa, R., Ito, S., Hatta, K., Nakamura, T., Yamamori, M., Miyamura, H., Murayama, Y., Kawamura, Y., Hayakawa, K., Tanaka, K., Tago, S., Ishigami, S., Mizukami, M., Tanaka, Y., 2000. Flour blends for deep fried foods, steamed Chinese manju, dough sheets, okonomi-yaki, and takoyaki. United States Patent 6,139,894.

Kiribuchi-Otobe, C., Nagamine, T., Yanagisawa, T., Ohnishi, M., Yamaguchi, I., 1997. Production of hexaploid wheats with waxy endosperm character. Cereal Chem. 74, 72-74.

Kruger, J.E., 1990. Instrumental assessment of sprout damaged wheat at primary or terminal receival points. Cereal Foods World 35, 935-939.

Lee, M.-R., Swanson, B.G., Baik, B.-K., 2001. Influence of amylose content on properties of wheat starch and breadmaking quality of starch and gluten blends. Cereal Chem. 78, 701-706.
Morris, C.F., Konzak, C.F., 2001. Registration of hard and soft homozygous waxy wheat germplasm. Crop Sci. 41, 934-935.

Morris, C.F., King, G.E., Rubenthaler, G.L., 1997. Contribution of wheat flour fractions to peak hot paste viscosity. Cereal Chem. 74, 147-153.

Nakamura, T., Yamamori, M., Hirano, H., Hidaka, S., Nagamine, T., 1995. Production of waxy (amylose-free) wheats. Mol. Gen. Genet. 248, 253-259.

Peterson, C.J., Graybosch, R.A., Baenziger, P.S., Grombacher, A.W., 1992. Genotype and environment effects on quality characteristics of hard red winter wheat. Crop Sci. 32, 98-103.

Peterson, C.J., Graybosch, R.A., Shelton, D.R., Baenziger, P.S., 1998. Baking quality and hard winter wheat: response of cultivars to environment in the Great Plains. Euphytica 100, 157-162.

Purdy, L.H., Loegering, W.Q., Konzak, C.F., Peterson, C.J., Allan, R.E., 1968. A proposed standard method for illustrating pedigrees of small grain varieties. Crop Sci. 8, 405-406.

Reddy, I., Seib, P.A., 2000. Modified waxy wheat starch compared to modified waxy corn starch.. J. Cereal Sci. 31, 25-29.

Takahashi, S., Seib, P.A., 1988. Paste and gel properties of prime corn and wheat starches with and without native lipids. Cereal Chem. 65, 74-83.

Udall, J.A., Souza, E., Anderson, J., Sorrells, M.E., Zemetra, R.S., 1999. Quantitative trait loci for flour viscosity in winter wheat. Crop Sci. 39, $238-242$.

Wootton, M., Panozzo, J.F., Hong, S.H., 1998. Differences in gelatinisation behaviour between starches from Australian wheat cultivars. StarchStarke 50, 154-158.

Zeng, M., Morris, C.F., Batey, I.L., Wrigley, C.W., 1997. Sources of variation for starch gelatinization, pasting and gelation properties in wheat. Cereal Chem. 74, 63-71. 